Журнал «Герспективитаінноваціїнауки»

(Серія «Педагогіка», Серія «Гиихологія», Серія«Медицина»

№5(5) 2021

УДК 159.922 .76

https://doi.org/10.52058/2786-4952 -2021-5(5)-512-522

Ніколасску Інна Олександрівна доктор педагогічних наук, доцент, т.в.о. завідувача кафедри дошкільної освіти, Черкаський національний університет імені Богдана Хмельницького, бул. Шевченка, 81, м. Черкаси, 18000, тел.: (0472) 372-142, e-mail: nikolaesky@ukr.net, https://orcid.org/0000-0002-9928-9291

Михальчук Олена Олександрівна кандидат педагогічних наук, доцент, доцент кафедри дошкільної освіти, Черкаський національний університет імені Богдана Хмельницького, бул. Шевченка, 81, м. Черкаси, 18000, тел.: (0472) 372-142, e-mail: mikhalchyklena@gmail.com, https://orcid.org/0000-0001-6991-0588

Нікітська Юлія Мирославівна кандидат педагогічних наук, старший викладач кафедри дошкільної освіти, Черкаський національний університет імені Богдана Хмельницького, бул. Шевченка, 81, м. Черкаси, 18000, тел.: (0472) 372-142, e-mail: nikitska.y@ outlook.com, https://orcid.org/0000-0002-0482-8011

\title{
ЗМІСТ ПСИХОЛОГО-ПЕДАГОГІЧНОГО СУПРОВОДУ ДІТЕЙ 3 ОСОБЛИВИМИ ОСВІТНІМИ ПОТРЕБАМИ
}

Анотація. Узагальнено актуальність розроблення програм психологопедагогічного супроводу дітей з особливими потребами, обгрунтовано потребу у переосмисленні ставлення до процедури інтеграції означеної категорії дітей у в освітнє середовище, що, в свою чергу, висуває нові вимоги до організації процесів навчання та виховання у закладах освіти. Висвітлено результати теоретичного аналізу сучасних досліджень порушеної проблематики та встановлено недостатньо розроблені її аспекти.

Потрактовано поняття психолого-педагогічного супроводу дітей 3 особливими освітніми потребами 3 позиції педагога, який виконує роль супроводжуючого індивідуальну освітню діяльність дитини. Ключовою метою реалізації зазначеного супроводу визначено створення соціально-педагогічних та психологічних умов, що сприяють успішному навчанню та розвитку кожної дитини в освітньому середовищі. Акцентовано увагу на значущості взаємодії всіх учасників освітньої діяльності (педагогів, психологів, батьків). Узагальнено завдання психолого-педагогічного супроводу дітей з особливими освітніми потребами, що полягають у: корекції та профілактиці соціальнопедагогічних та особистісних порушень у розвитку дитини; сприянні у вирішенні актуальних завдань розвитку та соціалізації; розвитку педагогічної компетентності батьків; створенні сприятливих соціально-педагогічних умов розвитку особистості; безпосередній психолого-педагогічній допомозі дитині 3 
особливими освітніми потребами та їі батькам.

Визначено найбільш значущі функції психолого-педагогічного супроводу дітей 3 особливими освітніми потребами: реабілітаційно-розвивальна, програмно-прогностична, корекційно-пропедевтична, діагностико-аналітична та координаційно-інтеграційна. Запропоновано базові принципи побудови процесу психолого-педагогічного супроводу дітей 3 особливими освітніми потребами: пріоритет інтересів дитини, системність, безперервність та опосередкованість, варіативність та рекомендаційний характер супроводу. Обгрунтовано послідовність основних етапів організації супроводу освітньої діяльності дітей з особливими освітніми потребами, зміст кожного 3 яких спрямовано на реалізацію мети та завдань діяльності супроводжуючого педагога у доцільній формі.

Ключові слова: психолого-педагогічний супровід, діти 3 особливими освітніми потребами, педагог, програма супроводу, завдання супроводу, форми супроводу.

Nikolaesku Inna Oleksandrivna Doctor of Pedagogical Science, Associate professor at the Department of Preschool Education, Bogdan Khmelnytsky National University at Cherkasy, Shevchenko Blv., 81, Cherkasy, 18000, tel.: (0472) 372-142, e-mail: nikolaesky@ukr.net, https://orcid.org/0000-0002-9928-9291

Mykhalchuk Olena Oleksandrivna PhD (Candidate of Pedagogical Sciences), Associate professor at the Department of Preschool Education, Bogdan Khmelnytsky National University at Cherkasy, Shevchenko Blv., 81, Cherkasy, 18000, tel.: (0472) 372-142, e-mail: mikhalchyklena@gmail.com, https://orcid.org/00000001-6991-0588

Nikitska Yuliia Myroslavivna PhD (Candidate of Pedagogical Sciences), Senior Lecturer at the Department of Preschool Education, Bohdan Khmelnytsky National University at Cherkasy, Shevchenko Blv., 81, Cherkasy, 18000, tel.: (0472) 372-142, e-mail: nikitska.y@outlook.com, https://orcid.org/0000-00020482-8011

\section{CONTENTS OF PSYCHOLOGICAL AND PEDAGOGICAL SUPPORT OF CHILDREN WITH SPECIAL EDUCATIONAL NEEDS}

Abstract. The urgency of developing programs of psychological and pedagogical support of children with special needs is generalized, the need to rethink the attitude to the procedure of integration of this category of children into the educational environment is substantiated, which, in turn, sets new requirements for teaching and education in educational institutions. The results of the theoretical analysis of modern researches of the raised problems are highlighted and its insufficiently developed aspects are established. 
The concept of psychological and pedagogical support of children with special educational needs from the position of a teacher who performs the role of accompanying individual educational activities of the child is analyzed. The key goal of the implementation of this support is to create socio-pedagogical and psychological conditions that contribute to the successful learning and development of each child in the educational environment. Emphasis is placed on the importance of interaction of all participants in educational activities (teachers, psychologists, parents). The tasks of psychological and pedagogical support of children with special educational needs are generalized, which consist in: correction and prevention of socio-pedagogical and personal disorders in the child's development; assistance in solving urgent problems of development and socialization; development of pedagogical competence of parents; creation of favorable socio-pedagogical conditions for personality development; direct psychological and pedagogical assistance to a child with special educational needs and her parents.

The most significant functions of psychological and pedagogical support of children with special educational needs are determined: rehabilitationdevelopmental, program-prognostic, correctional-propaedeutic, diagnostic-analytical and coordination-integration. The basic principles of building the process of psychological and pedagogical support of children with special educational needs are proposed: the priority of the child's interests, systemic, continuity and indirectness, variability and recommendatory nature of support. The sequence of the main stages of the organization of support of educational activity of children with special educational needs is substantiated, the maintenance of each of which is directed on realization of the purpose and tasks of activity of the accompanying teacher in the expedient form.

Keywords: psychological and pedagogical support, children with special educational needs, teacher, support program, support tasks, forms of support.

Постановка проблеми. На сучасному етапі розвитку системи освіти, перш за все висуваються нові вимоги до умов становлення особистості кожної дитини відповідно до особливостей іiі психічного та фізичного розвитку, можливостей та здібностей. Науковці наголошують, що інтеграція дітей 3 особливими освітніми потребами в освітнє середовище потребує переосмислення суспільством ставлення до цієї категорії дітей, визнання їх рівних прав на здобуття освіти, розробку конкретних програм супроводу дітей з особливими освітніми потребами для оптимальної реалізації можливостей їх вікових категорій. Таким чином, включення дітей $з$ особливими освітніми потребами у середовище дитячого колективу, вимагає значних змін в організації процесу навчання, актуалізує необхідність забезпечення комплексного психолого-педагогічного супроводу цієї категорії дітей протягом всього періоду навчання в умовах закладу освіти. Таким чином, психологопедагогічний супровід спрямований на забезпечення двох взаємоузгоджених процесів: супровід розвитку дитини та супровід процесу іiі навчання, 
виховання, корекції наявних відхилень (включає корекційну роботу, спрямовану на усунення чи послаблення наявних порушень, та розвивальну роботу, спрямовану на розкриття потенційних можливостей дитини, досягнення нею оптимального рівня розвитку); комплексна технологія, особливий шлях підтримки дитини, допомоги їй у вирішенні завдань розвитку, навчання, виховання, соціалізації [1].

Аналіз останніх досліджень і публікацій. Особливості реалізації психолого-педагогічного супроводу дітей різних вікових категорій 3 варіативними патологіями розвитку розкриті в наукових доробках відносно нерівнозначно. Так, це питання вивчається 3 урахуванням особливостей розвитку дітей із затримкою психічного розвитку Т. Калініною, Т. Сак та ін.; із порушеннями зору - В. Кобильченко, Т. Костенко та ін.; із синдромом Дауна Г. Міненко, Г. Соколовою та ін. Провідні теоретичні засади організації психологічного супроводу дітей 3 порушенням розвитку представлені в роботах О. Василькової, Є. Клопоти, В. Кобильченка, Т. Скрипник та ін. Але специфіка, сутність, етапи та функції реалізації психолого-педагогічного супроводу дітей із особливими освітніми потребами залишається недостатньо розробленою.

Мета статті полягає в грунтовному узагальненні та теоретичному аналізі сутності та функцій психолого-педагогічного супроводу дітей 3 особливими освітніми потребами.

Виклад основного матеріалу. Поняття «супровід» визначається тлумачним словником як «слідувати поруч, разом із будь-ким як супутник чи провідник». Запропоноване трактування визначає позицію педагога спеціальної освіти як супроводжуючого індивідуальну освітню діяльність дитини з особливими освітніми потребами у межах освітньої програми у конкретні сфері. У психолого-педагогічній літературі це поняття характеризується, насамперед, як процес, що передбачає створення психологічних та педагогічних умов, сприятливих для розвитку дитини, а поняття «супровід дітей $з$ особливими освітніми потребами» визначається як діяльність педагогів та спеціалістів (психологів та соціальних педагогів), спрямована на створення соціально-педагогічних та психологічних умов, що сприяють успішному навчанню та розвитку кожної дитини 3 особливими освітніми потребами в освітньому середовищі [2].

Грунтуючись на вищевказаних трактуваннях, психолого-педагогічний супровід дітей з особливими освітніми потребами можна визначити як процес взаємодії учасників освітньої діяльності (педагога, психолога, батьків) спрямованого формування освітнього простору, сприятливого для освоєння освітньої програми дітьми. Суб’єктами психолого-педагогічного супроводу у цьому випадку виступатимуть усі зацікавлені в успішній діяльності дитини особи, але провідна роль - організатора процесу у межах закладу освіти, безумовно, покладена на педагога, котрий безпосередньо реалізує освітню програму. Відтак, технологія психолого-педагогічного супроводу є алгоритмом 
діяльності педагога спеціальної освіти, реалізація якого створює дитині 3 особливими освітніми потребами умови для розвитку та прояву власних здібностей, а також сприяє іiі соціальній адаптації та реабілітації у дитячому колективі.

Наведені вище положення дозволяють визначити мету супроводу: створення комплексної системи психолого-педагогічних умов, що сприяють успішній адаптації, реабілітації та особистісному зростанню дитини 3 особливими освітніми потребами у дитячому освітньому колективі. За підсумками зазначеної мети можна визначити наступні завдання діяльності педагога спеціальної освіти у межах організації психолого-педагогічного супроводу дітей з особливими освітніми потребами у процесі опанування ними освітніх програм [3]:

- корекція та попередження виникнення проблем у розвитку дитини (соціально-педагогічні: соціальна дезадаптація, особистісні: невпевненість у собі, висока тривожність, неадекватна самооцінка, тощо);

- допомога (сприяння) дитині у вирішенні актуальних завдань розвитку та соціалізації: порушення емоційно-вольової сфери, проблеми у побудові взаємин з однолітками, педагогами, батьками;

- розвиток педагогічної компетентності (педагогічної культури) батьків, 3 метою перетворення їх на повноцінних суб'єктів психолого-педагогічного супроводу;

- створення сприятливих соціально-педагогічних умов розвитку особистості, успішність освоєння дитиною освітньої програми;

- безпосередня психолого-педагогічна допомога дитині з особливими освітніми потребами та ії батькам.

Поряд із зазначеними загальними метою та завданнями психологопедагогічного супроводу, при розробці його програми для конкретної особистості варто визначати специфічні цілі та завдання, грунтуючись на

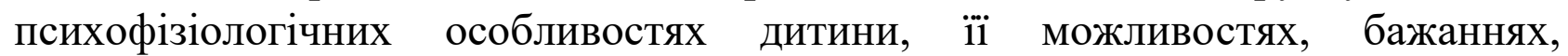
виховному потенціалі сім'ї. Програма психолого-педагогічного супроводу, що розробляється, повинна передбачати також реалізацію всіх його функцій. Як найбільш значущі у сфері супроводу дитини в спеціальній освіті варто виділити наступні функції $[4,5]$ :

- реабілітаційно-розвивальна, що передбачає організацію роботи 3 дитиною, спрямовану на ii реабілітацію в дитячому середовищі шляхом розвитку у неї значущих якостей, наявність яких допоможе компенсувати особливі освітні потреби;

- програмно-прогностична, що покликана забезпечувати впорядкованість дій суб'єктів освітнього процесу в рамках навчання, виховання та розвитку дитини, шляхом створення програми супроводу на основі проектування та прогнозування результатів, які може досягти дитина у процесі освоєння освітньої програми; 
- корекційно-пропедевтична, що забезпечує своєчасну допомогу дитині у подоланні недоліків розвитку шляхом своєчасного прогнозування виникнення пов'язаних $з$ ними проблем та розробки системи заходів, спрямованих на попередження можливих труднощів;

- діагностико-аналітична, котра визначає доцільність та необхідність систематичної діяльності з вивчення, оцінки та аналізу досягнень дитини в рамках освоєння нею освітньої програми шляхом здійснення моніторингу процесу індивідуального розвитку особистості, виявлення причин змін та визначення перспектив її особистісного зростання;

- координаційно-інтеграційна, спрямована на здійснення та підвищення ефективності процесу координації дій осіб, які беруть участь у роботі 3 дитиною, шляхом об'єднання зусиль та можливостей спеціалістів та сім'ї у виробленні найбільш сприятливої для дитини траєкторії розвитку в умовах дитячого колективу.

Зазначені функції психолого-педагогічного супроводу дитини 3 особливими освітніми потребами зумовлюють необхідність побудови процесу, що розглядається, на основі наступних базових принципів [6]:

- пріоритет інтересів дитини, що визначає партнерську позицію педагога спеціальної освіти, який покликаний вирішувати проблему дитини та організовувати розвивальну роботу 3 нею 3 максимальною користю та у іiі інтересах;

- системність, що забезпечує єдність діагностики, цілепокладання, планування, аналізу, корекції та розвитку, передбачає системний підхід до організації роботи 3 дітьми, що мають особливі освітні потреби, а також всебічна багаторівнева взаємодія фахівців різного профілю, узгодженість їх дій у вирішенні проблем дитини; участь в цьому процесі всіх зацікавлених осіб;

- безперервність та опосередкованість, реалізація принципу гарантує дитині та іiі батькам (законним представникам) безперервність та своєчасність допомоги на всіх етапах іiі діяльності з освоєння освітньої програми, а також передбачає опосередкований психолого-педагогічний вплив на дії суб'єкта супроводу, шляхом створення умов, що вимагають самостійного прийняття рішень у ситуаціях життєво-важливого вибору;

- варіативність, що обумовлює доцільність розробки інваріантної та варіативної складових програми психолого-педагогічного супроводу, що забезпечить можливість ії гнучкої реалізації для отримання освіти дітьми, що мають різні недоліки у фізичному та (або) психічному розвитку;

- рекомендаційний характер надання допомоги дитині та сім'ї в рамках супроводу, що дозволяє забезпечити дотримання гарантованих законодавством прав батьків (законних представників) дітей 3 особливими освітніми потребами, а саме: обирати форми здобуття дітьми освіти, заклади освіти, що реалізують освітні програми; захищати законні права та інтереси дітей, включаючи обов'язкове узгодження з батьками (законними представниками) питань, пов'язаних з особливостями діяльності, пояснення їм потенційних 
можливостей конкретної освітньої програми у вирішенні проблем реабілітації та розвитку їхньої дитини [7].

Впровадження вищезгаданих принципів у комплексі покликане забезпечити ефективну реалізацію етапів психолого-педагогічного супроводу дітей з особливими освітніми потребами у системі освіти. На основі аналізу психолого-педагогічної літератури з проблем організації супроводу освітньої діяльності дітей можна виділити його основні етапи. Їх послідовність обумовлена загальною логікою процесу надання допомоги дитині у вирішенні виникаючих проблем та підходами до впорядкування процесів навчання, виховання та розвитку дітей у рамках освітньої діяльності. Зміст кожного етапу спрямовано на реалізацію мети та завдань діяльності педагога 3 організації супроводу дітей з особливими освітніми потребами у сфері спеціальної освіти. Варто зазначити, що психолого-педагогічний супровід повинен починатися 3 візиту сім’і до закладу освіти, тобто важливо з самого початку надати їм допомогу у виборі програми, найбільш сприятливої для реабілітації та

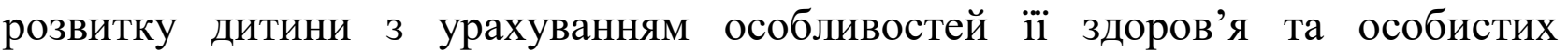
уподобань [8].

У зв'язку з вищенаведеним, першим етапом має стати діагностичний, що передбачає своєчасне виявлення у дитини труднощів, проведення комплексного психолого-педагогічного обстеження та підготовку рекомендацій щодо вибору сфери діяльності та надання допомоги в умовах закладу освіти. На цьому етапі можуть використовуватись такі форми: тестування, анкетування, опитування; діагностичні бесіди з дітьми та батьками. Реалізувати їх можуть педагоги спеціальної освіти за допомогою психолога.

Другий етап супроводу - договірний, він необхідний для забезпечення суб’єктної позиції всіх зацікавлених осіб (насамперед дитини та батьків) у процесі проектування індивідуального освітнього маршруту (програми індивідуального розвитку) дитини та на етапах супроводу пї освітньої діяльності. Також на цьому етапі формується мотиваційна база для активного включення дитини та батьків у взаємодію у межах освоєння освітньої програми.

Третім етапом супроводу $\epsilon$ аналітичний: він передбачає визначення особливих освітніх потреб дитини в рамках обраної освітньої програми та реалізується шляхом проведення консультацій за участю батьків, спеціалістів та педагогів. На основі зібраної про особливості розвитку дитини інформації, 3 урахуванням виявлених у процесі аналізу їі особливих освітніх потреб, а також беручи до уваги бажання дітей та батьків, педагог спеціальної освіти приступає до реалізації четвертого, прогностичного етапи супроводу. Цей етап передбачає: визначення особливостей організації освітнього процесу для дитини з особливими освітніми потребами; виділення цілей та завдань роботи щодо супроводу процесу освоєння нею освітньої програми; розробку цілей та завдань індивідуального та особистісного розвитку дитини засобами проведення психолого-педагогічного консиліуму та організації цілепокладання 
за участю дитини, фахівців та батьків.

П'ятий етап - проектувальний, продовжує роботу, розпочату на попередніх етапах супроводу, та дозволяє конкретизувати виділені цілі та завдання через розробку індивідуалізованих проектів освітньої діяльності та розвиток особистості дитини. Продуктами спільної діяльності учасників процесу проектування (педагогів, батьків, дитини, спеціалістів) можуть стати: індивідуальний освітній маршрут (освітня програма); індивідуальна корекційно-розвивальна програма; програма надання консультативної та методичної допомоги батькам дітей з особливими освітніми потребами.

Розроблені на попередньому етапі проекти реалізуються у межах шостого, організаційного етапу супроводу. Він передбачає безпосередню діяльність учасників освітнього процесу щодо створення умов, що сприяють реабілітації та розвитку дітей з особливими освітніми потребами у дитячому колективі. Цей етап передбачає здійснення наступних напрямів роботи: здійснення індивідуально орієнтованої психолого-педагогічної допомоги дитині; реалізація індивідуальних освітніх маршрутів та корекційно-розвивальних програм; надання консультативної та методичної допомоги батькам.

Наступний, сьомий етап супроводу - контрольно-коригувальний, що здійснюється не тільки після завершення шостого етапу, але й у процесі його перебігу. Це зумовлено тим, що вивчення та аналіз результатів реалізації індивідуальних освітніх маршрутів та корекційно-розвивальних програм потребує своєчасного внесення коректив до системи роботи 3 дитиною 3 урахуванням іiі досягнень та змін, що відбуваються в іiі розвитку [9]. На цьому етапі доцільно використовувати такі форми: діагностичні методики для вивчення проміжних та підсумкових результатів; опитування батьків, розмови з дітьми, встановлення зворотного зв'язку і виділення найефективніших форм роботи; організацію проміжних консультацій та психолого-педагогічних консиліумів 3 метою розробки системи змін, які необхідно внести до розроблених для дитини програм з урахуванням досягнутих нею результатів та перспектив подальшого розвитку.

Позначені вище етапи визначають найбільш значущі моменти психологопедагогічного супроводу, безумовно, вони можуть бути доповнені шляхом врахування особливостей дітей та специфіки окремих освітніх програм. Але, незалежно від кількості і змісту здійсненої роботи, важливо окрему увагу приділяти цілеспрямованій роботі щодо взаємодії педагога спеціальної освіти 3 фахівцями та батьками. На основі аналізу програм психолого-педагогічного супроводу дітей 3 особливими освітніми потребами, що розробляються закладами освіти, ми пропонуємо можливі форми здійснення такої взаємодії [10]:

1. Психологічна діагностика адаптаційного періоду: дослідження мотиваційної сфери: пізнавальна мотивація; дослідження емоційно-вольової сфери: самооцінка, емоційно-психологічний стан, тривожність, довільність діяльності та саморегуляції. 
Журнал«Герспектввита інновації наукцљ

(Серія«Гедагогіка», Серія«Гtиххологія», Серія«Медицинф»

№5(5) 2021

2. Проведення психолого-педагогічних консиліумів, навчальних семінарів, нарад з представниками адміністрації, педагогами та батьками.

3. Консультативна робота 3 педагогами, дітьми та батьками.

4. Профілактична робота (реалізація програм, спрямованих на вирішення проблем міжособистісної взаємодії).

5. Корекційно-розвивальна робота (індивідуальні та групові заняття 3 дітьми).

6. Консультації та бесіди 3 батьками щодо надання допомоги дітям в освоєнні освітньої програми.

7. Консультації батьків та дітей 3 психологом, логопедом, соціальним педагогом.

Висновки. Таким чином, ми розглянули найбільш значущі на наш погляд особливості психолого-педагогічного супроводу дітей з особливими освітніми потребами в межах спеціальної освіти. Варто зазначити, що педагог спеціальної освіти у власній супровідній діяльності та під час реалізації конкретної освітньої програми з одного боку має спиратися на базові підходи до супроводу дітей цієї категорії, 3 іншого - будувати іiі, враховуючи особливості супроводжуваних та специфіку тієї освітньої діяльності, до якої вони включаються. 3 урахуванням зазначеного положення слід зробити висновок, що програми супроводу, що розробляються педагогами спеціальної освіти, відрізнятимуться високим ступенем варіативності та індивідуалізованості, тому не можуть бути реалізовані в тому самому вигляді в різних дитячих колективах. Проте, існуючий у спеціальній освіті досвід супроводу дітей 3 особливими освітніми потребами повинен вивчатися та використовуватися педагогом для проектування змісту власної супроводжуючої діяльності.

\section{Лimepamypa:}

1. Гречко Л. М. Психологічний супровід дітей молодшого шкільного віку з вадами психофізичного розвитку в умовах інтегрованого навчання: дис. ... канд. психол. наук : 19.00.08. Київ, 2018. 320 с.

2. Крутій К. Концептуальні засади психолого-педагогічного супроводу: принципи і техніки. Актуальні проблеми психолого-педагогічного та соціального супроводу дитини на ранніх етапах соціалізації. Гуманізація навчально-виховного процесу. Слов'янськ, 2015. Ч. 1. № 4. С. 185 - 198.

3. Хохліна О. П. Психолого-педагогічні засади виховання, розвитку та сприяння соціальнопобутовій адаптації дітей шкільного віку 3 помірною та тяжкою розумовою відсталістю. Психолого-педагогічний супровід дітей шкільного віку 3 помірною та тяжкою розумовою відсталістю / за ред. В. І. Бондаря, В. В. Засенка. Київ: ТОВ «Поліпром», 2016. С. 4 - 19.

4. Бех І. Д. Психологічний супровід особистісно зорієнтованого виховання. Початкова школа. 2004. № 3. С. 3 - 6.

5. Кобильченко В. В., Бойчук Ю. Д., Сіліна О. Г. Дитина 3 особливими освітніми потребами: медичні та психолого-педагогічні аспекти розвитку, навчання і виховання: навчально-методичний посібник. Харків: Харківська академія неперервної освіти. Видавництво «Точка», 2015. 292 с.

6. Діти і соціум: особливості соціалізації дітей дошкільного та молодшого шкільного віку : монографія / За заг. ред. Н. В. Гавриш. Луганськ : Альма-матер, 2016. 368 с. 
7. Засенко В. В. До проблеми особистісного підходу у навчанні дітей з порушеннями психофізичного розвитку. Дидактичні та соціально-психологічні аспекти корекційної роботи у спеціальній школі: наук.- метод. зб. / за ред.: В. І. Бондаря, В. В. Засенка. Київ : Науковий світ, 2018. Вип. 8. С. $85-88$.

8. Колупаєва А. А. Діти з особливими потребами та організація їх навчання. (Серія «ннклюзивна освіта»). Київ : Науковий світ, 2015. 260 с.

9. Синьов В. М. Психолого-педагогічні проблеми дефектології та пенітенціарії. Київ : «МП Леся», 2018. 779 с.

10. Сак Т. В. Диференційований підхід до навчання учнів з особливими освітніми потребами. Науковий часопис НПУ ім. М. П. Драгоманова. Серія 19 : Корекційна педагогіка та спеціальна психологія. 2019. Вип. 26. С. 215 - 219.

\section{References:}

1. Hrechko, L. M. (2018) Psykholohichnyi suprovid ditei molodshoho shkilnoho viku z vadamy psykhofizychnoho rozvytku v umovakh intehrovanoho navchannia [Psychological support of primary school children with mental and physical disabilities in the context of integrated learning] : dys. ... kand. psykhol. nauk : 19.00.08. Kyiv. 320 [in Ukrainian].

2. Krutii, K. (2015) Kontseptualni zasady psykholoho-pedahohichnoho suprovodu: pryntsypy i tekhniky. Aktualni problemy psykholoho-pedahohichnoho ta sotsialnoho suprovodu dytyny na rannikh etapakh sotsializatsii [Conceptual principles of psychological and pedagogical support: principles and techniques. Current issues of psychological, pedagogical and social support of the child in the early stages of socialization]. Humanizatsiia navchalno-vykhovnoho protsesu Humanization of the educational process. Sloviansk. 1. 4. 185 - 198 [in Ukrainian].

3. Khokhlina, O. P. (2016) Psykholoho-pedahohichni zasady vykhovannia, rozvytku ta spryiannia sotsialno-pobutovii adaptatsii ditei shkilnoho viku z pomirnoiu ta tiazhkoiu rozumovoiu vidstalistiu. Psykholoho-pedahohichnyi suprovid ditei shkilnoho viku $\mathrm{z}$ pomirnoiu ta tiazhkoiu rozumovoiu vidstalistiu [Psychological and pedagogical principles of education, development and promotion of social and domestic adaptation of school-age children with moderate and severe mental retardation. Psychological and pedagogical support of school-age children with moderate and severe mental retardation] / za red. V. I. Bondaria, V. V. Zasenka. Kyiv: TOV «Poliprom». 4 - 19 [in Ukrainian].

4. Bekh, I. D. (2014) Psykholohichnyi suprovid osobystisno zoriientovanoho vykhovannia [Psychological support of personality-oriented education]. Pochatkova shkola-Initial school. 3.3 -6 [in Ukrainian].

5. Kobylchenko, V. V., Boichuk, Yu. D., Silina, O. H. (2015) Dytyna z osoblyvymy osvitnimy potrebamy: medychni ta psykholoho-pedahohichni aspekty rozvytku, navchannia i vykhovannia: navchalno-metodychnyi posibnyk [A child with special educational needs: medical and psychological and pedagogical aspects of development, training and education: a textbook]. Kharkiv: Kharkivska akademiia neperervnoi osvity. Vydavnytstvo «Tochka». 292 [in Ukrainian].

6. Dity i sotsium: Osoblyvosti sotsializatsii ditei doshkilnoho ta molodshoho shkilnoho viku [Children and society: Features of socialization of children of preschool and primary school age] : monohrafiia / Za zah. red. N. V. Havrysh. Luhansk : Alma-mater, 2016. 368 [in Ukrainian].

7. Zasenko, V. V. (2018) Do problemy osobystisnoho pidkhodu u navchanni ditei z porushenniamy psykhofizychnoho rozvytku. Dydaktychni ta sotsialno-psykholohichni aspekty korektsiinoi roboty u spetsialnii shkoli: nauk.- metod. zb. [To the problem of personal approach in teaching children with mental and physical disabilities. Didactic and socio-psychological aspects of correctional work in a special school] / za red.: V. I. Bondaria, V. V. Zasenka. Kyiv : Naukovyi svit. 8. 85-88.

8. Kolupaieva, A. A. (2015) Dity z osoblyvymy potrebamy ta orhanizatsiia yikh navchannia. (Seriia «Inkliuzyvna osvita») [Children with special needs and organization of their education. (Inclusive Education Series)]. Kyiv : Naukovyi svit. 260 [in Ukrainian]. 
9. Synov, V. M. (2018) Psykholoho-pedahohichni problemy defektolohii ta penitentsiarii [Psychological and pedagogical problems of defectology and penitentiary]. Kyiv : «MP Lesia». 779 [in Ukrainian].

10. Sak, T. V. (2019) Dyferentsiiovanyi pidkhid do navchannia uchniv z osoblyvymy osvitnimy potrebamy [Differentiated approach to teaching students with special educational needs]. Naukovyi chasopys NPU im. M. P. Drahomanova - Scientific journal of NPU named after M.P. Dragomanova. Seriia 19 : Korektsiina pedahohika ta spetsialna psykholohiia. 26. $215-219$ [in Ukrainian]. 